\title{
Compression Strength of Fir and Beech Wood Modified by Citric Acid
}

\section{Čvrstoća na tlak jelovine i bukovine modificirane limunskom kiselinom}

\author{
Original scientific paper • Izvorni znanstveni rad \\ Received-prispjelo: 20. 7. 2011. \\ Accepted-prihvaćeno: 9. 2. 2012. \\ UDK: $630 * 812.72 ; 630 * 841.61 ; 674.032 .475 .242 ; 674.031 .632 .22$ \\ doi:10.5552/drind.2012.1123
}

\begin{abstract}
Previous articles have shown that modification of wood by citric acid (CA) improves dimensional stability and resistance of wood against fungi attack. However, chemical modification of wood also modifies its mechanical properties in some way. The compression strength of wood is one of its representative mechanical properties. Modified wood with lower values of compression strength has limited purpose. The intention of this work is to show the effect of wood modification by citric acid on the compression strength of wood.

Fir wood (Abies alba Mill.) and beech wood (Fagus sylvatica L.) were impregnated by citric acid with sodium-dihydrogen-hypophosphite ( $\mathrm{NaH}_{2} \mathrm{PO}_{2}$ ) as a catalyst. Part of the impregnated samples together with control samples were cured at the temperature of $140{ }^{\circ} \mathrm{C}$ for 10 hours and the remaining samples were cured in microwaves for 35 minutes. The average compression strength parallel to the grain of wood modified by $C A$, using different regimes of curing, was compared to the strength of unmodified wood. The average compression strength parallel to the grain of wood was retained after modification. In the case of fir wood, the average compression strength was even improved after modification. The results indicate that wood modified by citric acid may be considered for the purposes where compression strength properties are equally important as improved durability and dimensional stability of wood.
\end{abstract}

Keywords: Fir wood (Abies alba Mill.), beech wood (Fagus sylvatica L.), chemical modification, citric acid (CA), compression strength

\begin{abstract}
SAŽETAK - Objavljeni su radovi pokazali da se modifikacijom drva limunskom kiselinom poboljšava stabilnost dimenzija drva i njegova otpornost na djelovanje gljiva. Međutim, kemijska modifikacija drva na neki način mijenja i mehanička svojstva drva. Tlačna je čvrstoća jedno od bitnih mehaničkih svojstava drva. Modificirano drvo sniženih vrijednosti tlačne čvrstoće ima ograničenu upotrebu. Cilj rada bio je pokazati učinak modifikacije drva limunskom kiselinom (CA) na tlačnu čvrstoću drva. Drvo jele (Abies alba Mill.) i bukve (Fagus sylvatica L.) impregnirano je limunskom kiselinom uz dodatak natrij-dihidrohen-hipofosfita ( $\left.\mathrm{NaH}_{2} \mathrm{PO}_{2}\right)$ kao katalizatora. Dio impregniranih uzoraka zagrijavan je zajedno s kontrolnim uzrocima pri temperaturi od $140^{\circ} \mathrm{C}$ deset sati, a drugi je dio 35 minuta bio izložen mikrovalovima. U radu je uspoređena prosječna čvrstoća na tlak paralelno s vlakancima modificiranog drva zagrijavanoga različitim postupcima s odgovarajućom čvrstoćom nemodificiranoga drva. Prosječna čvrstoća na tlak paralelno s vlakancima drva zadržana je i nakon modifikacije. Prosječna čvrstoća na tlak modificirane jelovine čak je i povećana u usporedbi s nemodificiranom. Rezultati upućuju na mogućnost

\footnotetext{
${ }^{1}$ The authors are assistant professor, associate professor, associate professor, assistant and assistant researcher at the Faculty of Forestry, University of Zagreb, Zagreb, Croatia.

Autori su docent, izvanredna profesorica, izvanredni profesor, viši asistent i znanstvena novakinja Šumarskog fakulteta Sveučilišta u Zagrebu, Zagreb, Hrvatska.
} 
primjene drva modificiranoga limunskom kiselinom i za one namjene u kojima je uz povećanu stabilnost dimenzija i trajnost drva važna i tlačna čvrstoća drva.

Ključne riječi: drvo jele (Abies alba Mill.), drvo bukve (Fagus sylvatica L.), kemijska modifikacija, limunska kiselina (CA), čvrstoća na tlak

\section{INTRODUCTION 1. UVOD}

Wood is a natural renewable material that can be used for different purposes. In spite of its benefits, it has some disadvantages that limit its utility value. Wood can be degraded by microorganisms, xylophages (insects), UV rays. It is flammable and hygroscopic, and it changes dimensions at specific moisture contents with different air humidity. All the above mentioned disadvantages limit wood use compared to other new materials. There are many methods developed to reduce or even eliminate undesired wood properties. One of them is the chemical modification of wood. The main goal of the said modification is to improve dimensional stability and durability of wood, while retaining its mechanical properties.

The chemical modification of wood is the reaction of a chemical reagent with the hydroxyl groups of holocellulose and lignin (Militz et al, 1997).

Over $90 \%$ of cotton textiles consist of cellulose, while the percentage of cellulose in the wood is about 40 $-50 \%$. Large percentage of cellulose in the wood explains the fact that impregnation solutions suitable for durable-press finishing of cellulose textile materials can be efficiently applied to the wood. One of them is 1.3 dimethylol-4.5-dihydroxyethyleneurea (DMDHEU), which is successfully introduced to wood (Nicholas and Williams, 1987; Militz, 1993; Krause et al, 2003; Schaffert et al, 2005; Wepner and Militz, 2005; Hill, 2006).

Due to chemical modification of wood, its mechanical properties may be improved, reduced or retained. Chemical modification of wood may reduce its water absorption, which can also lead to improving its mechanical properties. Mechanical properties of wood can be improved by wood acetylating (Akitsu et al, 1993; Goldstein et al, 1961; Militz, 1991). On the other hand the degradation of wood cell wall by acid chemicals and higher temperature of thermocondensation during the wood modification process (i.e. etherification with alkyl chloride) can cause loss of strength. Some authors reported great strength loss of wood modified by DMDHEU due to acid degradation of the cell wall (Nicholas and Wiliams, 1987; Hill, 2006).

Xie et al. (2007) reported great loss of tensile strength of thin veneer strips modified by DMDHEU, determined by a thin-veneer strip technique (Turkulin and Sell, 2002). According to them the cause is probably in the catalyst and namely magnesium chloride, which makes complex compounds with DMDHEU directly affecting the loss of wood strength. Another factor that limits the application of DMDHEU is hydrolytic formaldehyde release at elevated temperatures of processing, so new environmentally friendly chemicals have been introduced. One of them is citric acid (CA).

Katović et al. (1994) esterified solid fir and beech wood with citric acid (CA) and $\mathrm{NaH}_{2} \mathrm{PO}_{2}$ (SHP) as a catalyst. First results reported good improvement in wood stability giving guidelines to other researchers. Hasan et al. (2006, 2007) and Despot et al. (2008) reported multiple increasing of biological durability of pine sapwood modified by CA.

Bischof Vukusic et al. (2006) described the effect of wood modification by CA on the reduction of water uptake and swelling of small wooden blocks. They compared the results with those obtained using DMDHEU as the modifying chemical.

In the present study we also focus on microwave curing. Microwave dielectric heating is based on the activation of polar molecules in the treated medium (polarization phenomenon). Cellulose, hemicelluloses and lignin are polar polymers whose electric properties are defined by polarization processes that take place because of the interactions between the molecules of the wood and the external field (Torgovnikov, 1993). Microwaves allow more uniform and faster heating of the whole volume, not just the surface. An additional advantage of the MW treatment lies in the fact that the energy (heat) and the mass (water) flow are travelling in the same direction. These advantages are additional reasons to use microwaves for drying. Furthermore, the energy consumption is 60-70\% lower in the case of microwave treatment (Metaxas and Meredith, 1982).

In addition to all above, so far there has been no report on mechanical properties of wood modified by $\mathrm{CA}$, although mechanical properties can also be expected to be modified. The compression strength of wood is one of its representative mechanical properties. Modified wood with lower values of compression strength has limited purpose. The intention of this work is to show the effect of wood modification by citric acid on the compression strength of wood.

\section{MATERIALS AND METHODS}

\section{MATERIJALI I METODE}

Lattices with dimensions $20 \times 20 \times 800 \mathrm{~mm}(T \mathrm{x}$ $R \times L$ ) were sawn from air-dried radial boards of fir wood and beech wood. Samples with dimensions $20 \mathrm{x}$ $20 \times 40 \mathrm{~mm}(T \times R \times L)$ were sawn and signed in succession (Fig. 1).

In this work water solutions of citric acid (CA) have been applied with $\mathrm{NaH}_{2} \mathrm{PO}_{2}$ as a catalyst.

After conditioning at $20^{\circ} \mathrm{C}$ and $65 \%$ relative humidity, part of the samples $\left(\mathrm{C}_{\mathrm{t}}\right.$ and $\left.\mathrm{C}_{\mathrm{mw}}\right)$ was impregnated with citric acid solution. The part of control sam- 
Table 1 Parameters in modification processes

Tablica 1. Parametri u procesima modifikacije

\begin{tabular}{|c|c|c|c|c|}
\hline $\begin{array}{c}\text { Treatment } \\
\text { Vrsta obrade }\end{array}$ & $\begin{array}{c}\text { Agent } \\
\text { Kemikalija }\end{array}$ & $\begin{array}{c}\text { Catalyst } \\
\text { Katalizator }\end{array}$ & $\begin{array}{c}\text { Convection heating } \\
\text { Konvekcijsko zagrijavanje }\end{array}$ & $\begin{array}{c}\text { Microwave treatment } \\
\text { Zagrijavanje mikrovalovima }\end{array}$ \\
\hline $\mathrm{C} 1$ & $/$ & $/$ & $20{ }^{\circ} \mathrm{C}$ & $/$ \\
\hline $\mathrm{C} 2$ & $\mathrm{H}_{2} \mathrm{O}$ & $/$ & $140{ }^{\circ} \mathrm{C}, t=10 \mathrm{~h}$ & $/$ \\
\hline $\mathrm{C} 3$ & $\mathrm{H}_{2} \mathrm{O}$ & $/$ & $/$ & $P=750 \mathrm{~W}, t=35 \mathrm{~min}$ \\
\hline $\mathrm{C}-\mathrm{t}$ & $7 \% \mathrm{CA}$ & $6,5 \% \mathrm{NaH}_{2} \mathrm{PO}_{2}$ & $140{ }^{\circ} \mathrm{C}, t=10 \mathrm{~h}$ & $/$ \\
\hline $\mathrm{C}-\mathrm{mw}$ & $7 \% \mathrm{CA}$ & $6,5 \% \mathrm{NaH}_{2} \mathrm{PO}_{2}$ & $/$ & $P=750 \mathrm{~W}, t=35 \mathrm{~min}$ \\
\hline
\end{tabular}

ples (C2 and C3) was impregnated with distilled water, and the rest $(\mathrm{C} 1)$ was left unimpregnated.

The number of parallel samples (series) was 30 (Figure 1).

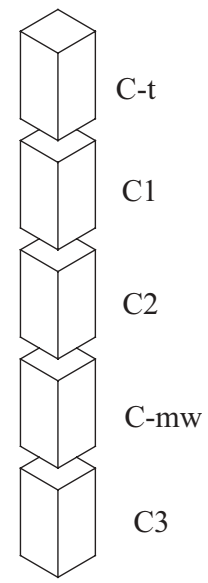

Figure 1 Succession of wood samples in quarter sawn boards

Slika 1. Redoslijed uzimanja uzoraka od četvrtača

The impregnation cycle consisted of a 5-minute initial vacuum of $2 \mathrm{kPa}$. The vacuum vessel was then filled with treating solutions and the vacuum of $2 \mathrm{kPa}$ was maintained for $3 \mathrm{~h}$, followed with an $18 \mathrm{~h}$ soaking at atmospheric pressure (Katović et al, 2004; Bischof Vukusic et al, 2006).

Impregnated samples were air-dried and then cured in oven at the temperature of $140{ }^{\circ} \mathrm{C}$ for 10 hours
(C-t) or in microwaves for 35 minutes (C-mw). After thermocondensation the samples were conditioned in climate chamber $\left(20^{\circ} \mathrm{C}\right.$ and $65 \%$ relative humidity) before wood strength measurements. To separate the effect of curing procedures from the effect of chemical modification on mechanical properties of wood, control samples $\mathrm{C} 2$ and $\mathrm{C} 3$ were used.

Compression strength measurements parallel to the grain were performed in accordance with HRN D. A1.045 using Wolpert - universal machine for the determination of mechanical properties.

\section{RESULTS AND DISCUSSION}

\section{REZULTATI I DISKUSIJA}

The compression strength parallel to the grain of unmodified fir wood was $52 \mathrm{MPa}$ in average and of beech wood it was $73 \mathrm{MPa}$ (Table 2).

Compression strength values of unmodified wood are in accordance with other authors (Wagenfuhr, 1974; Govorčin et al, 2001, 2003). After curing at the temperature of $140{ }^{\circ} \mathrm{C}$ for 10 hours, the average compression strength of fir wood slightly increased (Figure 2), although not significantly, while the average compression strength of beech wood remained unchanged (Figure 3).

In the case of microwave treatment, the average compression strength of fir wood was unchanged while the average compression strength of beech wood increased slightly but not significantly after microwave treatment. This results show that curing itself at the tempera-

Table 2 Compression strength parallel to the grain of modified and unmodified wood

Tablica 2. Čvrstoća na tlak paralelno s vlakancima modificiranoga i nemodificiranog drva

\begin{tabular}{|c|c|c|c|c|c|}
\hline \multirow{2}{*}{$\begin{array}{l}\text { Wood species } \\
\text { Vrsta drva }\end{array}$} & \multirow{2}{*}{$\begin{array}{l}\text { Type of treatment } \\
\text { Vrsta obrade }\end{array}$} & \multicolumn{2}{|c|}{$\begin{array}{c}\text { Convection heating } \\
\text { Konvekcijsko zagrijavanje }\end{array}$} & \multicolumn{2}{|c|}{$\begin{array}{c}\text { Microwave treatment } \\
\text { Zagrijavanje mikrovalovima }\end{array}$} \\
\hline & & $\begin{array}{l}\sigma_{\mathrm{t} I I} \\
\mathrm{MPa}\end{array}$ & c.v. & $\begin{array}{c}\sigma_{\mathrm{t} \text { II }} \\
\mathrm{MPa}\end{array}$ & c.v. \\
\hline \multirow{5}{*}{$\begin{array}{c}\text { Fir wood } \\
\text { jelovina (Abies alba Mill.) }\end{array}$} & $\mathrm{C} 1$ & 52 & 4 & 1 & 1 \\
\hline & $\mathrm{C} 2$ & 54 & 5 & 1 & 1 \\
\hline & $\mathrm{C} 3$ & 1 & 1 & 52 & 5 \\
\hline & $C-t$ & 57 & 9 & & \\
\hline & C-mw & 1 & 1 & 46 & 9 \\
\hline \multirow{5}{*}{$\begin{array}{l}\text { Beech wood bukovina } \\
\text { (Fagus sylvatica L.) }\end{array}$} & $\mathrm{C} 1$ & 73 & 7 & 1 & 1 \\
\hline & $\mathrm{C} 2$ & 73 & 7 & 1 & 1 \\
\hline & $\mathrm{C} 3$ & 1 & 1 & 72 & 5 \\
\hline & C-t & 76 & 9 & 1 & 1 \\
\hline & C-mw & 1 & 1 & 74 & 7 \\
\hline
\end{tabular}

$\sigma_{\mathrm{t} \text { II }}$ - compression strength parallel to the grain / čvrstoća na tlak paralelno s vlakancima,

c.v. - coefficient of variation / koeficijent varijacije 
Šefc, Trajković, Sinković, Hasan, Ištok: Compression Strength of Fir and Beech Wood... .....

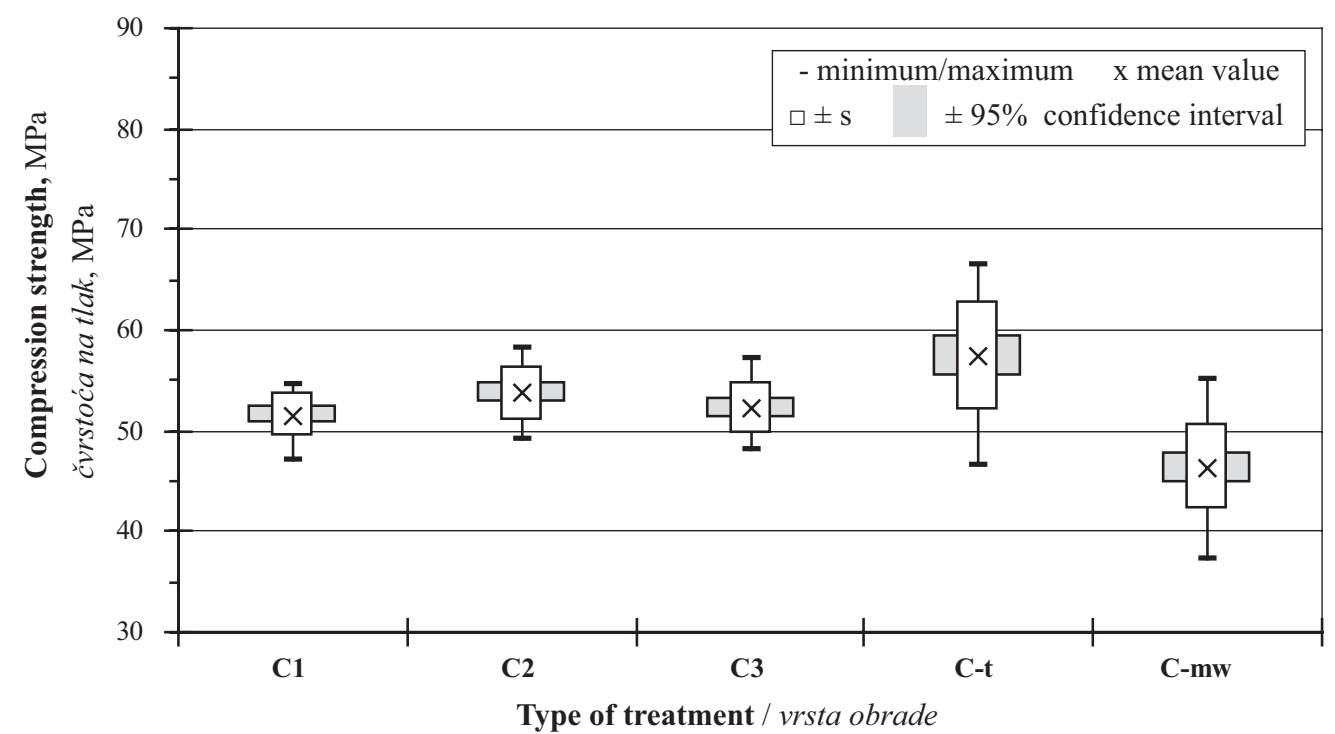

Figure 2 Statistical comparison of the compression strength of fir wood $\left(\mathrm{C} 1-\right.$ Control samples conditioned at $t=20{ }^{\circ} \mathrm{C}$ and $\varphi$ $=65 \% ; \mathrm{C} 2-\mathrm{Control}$ samples cured at the temperature of $140{ }^{\circ} \mathrm{C} ; \mathrm{C} 3-\mathrm{Control}$ samples cured in microwaves; $\mathrm{C}-\mathrm{t}-\mathrm{Samples}$ impregnated by CA solution and cured at the temperature of $140{ }^{\circ} \mathrm{C} ; \mathrm{C}-\mathrm{mw}-$ Samples impregnated by CA solution and cured by microwaves)

Slika 2. Statistička usporedba čvrstoće jelovine na tlak (C1 - kondicionirani kontrolni uzorci: $t=20^{\circ} \mathrm{C}$ i $\varphi=65 \%$; $\mathrm{C} 2-$ kontrolni uzorci zagrijavani pri temperaturi $140{ }^{\circ} \mathrm{C}$; $\mathrm{C} 3$ - kontrolni uzorci zagrijavani mikrovalovima; C-t - uzorci impregnirani otopinom CA i zagrijavani pri temperaturi $140^{\circ} \mathrm{C}$; C-mw - uzorci impregnirani otopinom CA i zagrijavani mikrovalovima)

ture of $140{ }^{\circ} \mathrm{C}$ or by microwaves has almost no influence on the average compression strength of wood.

When fir wood was modified by CA at the temperature of $140{ }^{\circ} \mathrm{C}$, the average compression strength increased significantly from $52 \mathrm{MPa}$ (unmodified wood) to $57 \mathrm{MPa}$ (modified wood) (Figure 2, Table 2). However, the range of compression strength values of modified fir wood was doubled compared to the unmodified wood. In the case of beech wood, the average increase of compression strength also occurred due to wood modification, but the increase was insignificant (Figure 3 , Table 2). The amount of CA bound to wood is significantly larger in fir wood (Katović et al, 2006). Higher average compression strength of modified fir wood can be explained by better crosslinking of CA and wood.

On the other hand, a significant decrease in average compression strength of modified fir wood cured by microwaves was observed. It is possible that during MW treatment in some fir wood samples micro-splits occurred due to low permeability of wood. The range

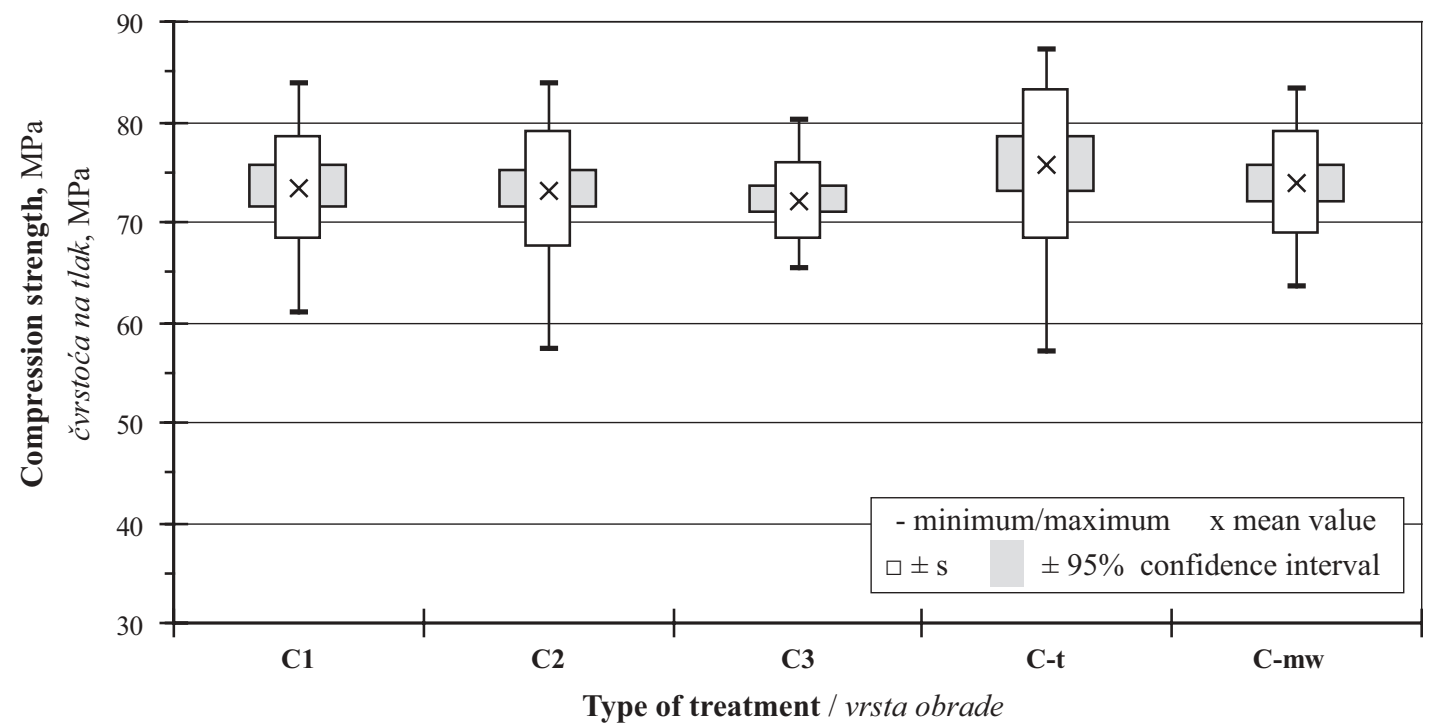

Figure 3 Statistical comparison of the compression strength of beech wood $\left(\mathrm{C} 1-\right.$ Control samples conditioned at $t=20^{\circ} \mathrm{C}$ and $\varphi=65 \% ; \mathrm{C} 2$ - Control samples cured at the temperature of $140{ }^{\circ} \mathrm{C} ; \mathrm{C} 3$ - Control samples cured in microwaves; C-t Samples impregnated by CA solution and cured at the temperature of $140{ }^{\circ} \mathrm{C} ; \mathrm{C}-\mathrm{mw}-\mathrm{Samples}$ impregnated by CA solution and cured by microwaves)

Slika 3. Statistička usporedba čvrstoće bukovine na tlak $\left(\mathrm{C} 1\right.$ - kondicionirani kontrolni uzorci: $t=20^{\circ} \mathrm{C}$ i $\varphi=65 \%$; $\mathrm{C} 2-$ kontrolni uzorci zagrijavani pri temperaturi $140^{\circ} \mathrm{C}$; $\mathrm{C} 3$ - kontrolni uzorci zagrijavani mikrovalovima; $\mathrm{C}$-t - uzorci impregnirani otopinom CA i zagrijavani pri temperaturi $140^{\circ} \mathrm{C}$; C-mw - uzorci impregnirani otopinom CA i zagrijavani mikrovalovima) 
of compression strength values of modified fir wood was doubled compared to the unmodified wood. It did not happen in the case of beech wood. The compression strength of beech wood modified in microwaves was unchanged. One can assume that low permeability of fir wood in contrast to beech wood contributed to uneven distribution of chemical bound to the wood, and that both factors led to doubled range of compression strength values in modified fir wood.

These results indicate the need of control over more parameters during microwave treatment to achieve better results.

\section{CONCLUSIONS}

4. ZAKLJUČCI

Exposure of wood to the temperature of $140^{\circ} \mathrm{C}$ for 10 hours or to intermittent power of $750 \mathrm{~W} \mathrm{mi-}$ crowaves for 35 minutes has little or no influence on changing the average compression strength of wood.

The process of fir wood and beech wood modification by $\mathrm{CA}$ in which wood was cured at $140{ }^{\circ} \mathrm{C}$ for 10 hours resulted in the improvement of the average compression strength of wood. The improvement was significant in fir wood and insignificant in beech wood.

One of the important goals of chemical modifications - to get wood with unchanged strength properties, has been achieved.

When intermittent power of $750 \mathrm{~W}$ microwaves was used for 35 minutes for curing, there was no improvement of the average compression strength. Instead, the average compression strength of fir wood decreased and in beech wood it was retained during the process.

In addition to improved dimensional stability and resistance of wood against fungi attack, retaining or even improving the average compression strength of wood modified by CA confirms CA as a successful chemical in wood modification process.

However, further research is needed on more parameters for predicting the mechanical properties of modified wood.

\section{REFERENCES}

\section{LITERATURA}

1. Akitsu, H.; Norimoto, M.; Morooka, T.; Rowell, R. M., 1993: Effect of humidity on vibrational properties of chemically modified wood. Wood and Fiber Science 25(3): 250-260.

2. Bischof Vukušić, S.; Katović, D.; Schramm, C.; Trajković, J.; Šefc, B., 2006: Polycarboxylic acids as non-formaldehyde antiswelling agents for wood. Holzforschung 60:439-444, http://dx.doi.org/10.1515/HF.2006.069.

3. Despot, R.; Hasan, M.; Jug, M.; Šefc, B., 2008: Biological durability of wood modified by citric acid, Drvna industrija, 59(2): 55-59.

4. Goldstein, I. S.; Jeroski, E. B.; Lund, A. E.; Nielson, J. F.; Weaver, J. W., 1961: Acetylation of wood in lumber thickness. Forest Products Journal 11(8): 363-370.
5. Govorčin, S.; Sertić, V.; Despot, R.; Trajković, J.; Sinković, T., 2001: Obična jela (Abies alba Mill.) u Hrvatskoj, glavni urednik prof. em. dr. sc. dr. h. c. Branimir Prpić, Zagreb, 733-748.

6. Govorčin, S.; Sinković, T.; Trajković, J.; Despot, R., 2003: Obična bukva (Fagus sylvatica L.) u Hrvatskoj, glavni urednik prof. em. dr. sc. dr. h. c. Slavko Matić, Zagreb, 652-664.

7. Hasan, M.; Despot, R.; Trajković, J.; Šefc, B., 2006: Role of modification processes at increasing biological durability of wood. International conference European Union Challenges and perspectives for the wood-processing industry, Zagreb, October 13th, Proceedings, pp. 153-158.

8. Hasan, M.; Despot, R.; Katović, D.; Bischof Vukušić, S.; Bogner, A.; Jambreković, V. 2007: Citric Acid - Promising Agent for Increased Biological Durability of Wood. 3rd European Conference on Wood Modification, Cardiff UK, October 15-16th, Proceedings, pp. 275-278.

9. Hill, C. A. S., 2006: Wood Modification: Chemical, Thermal and other processes. Wiley, UK, pp. 260 (Hill 2006).

10. HRN D. A1.045 - Hrvatska norma za ispitvanje čvrstoće na tlak paralelno sa vlakancima drva.

11. Katović, D.; Bischof Vukušić, S.; Trajković, J.; Šefc, B., 2004: Alternativna sredstva i postupci kemijske modifikacije drva, Drvna industrija, 55(4): 175-180.

12. Krause, A.; Jones, D.; Van der Zee, M.; Militz, H., 2003: Interlace Treatment - Wood modification with -Methylol Compounds. Proceedings of the first European Conference on Wood Modification. Vsn Acker, J.; Hill, C.A.S. (Ed). Ghent, Belgium. Pp. 317-327.

13. Bangor University, Cardiff, Wales, pp. 49-56.

14. Metaxas, A. C.; Meredith, R. J., 1982: Industrial Microwave Heating, Peter Peregrinus, London, UK.

15. Militz, H., 1991: Improvements of stability and durability of Beechwood (Fagus sylvatica) by means of treatment with acetic anhydride. The International Research Group on Wood Preservation. Document No.: IRG/WP 3645.

16. Militz, H.. 1993: Treatment of timber with water soluble dimethylol resins to imrpove their dimensional stability and durability. Wood Science and Technology 27():347355.

17. Militz, H.; Beckers, E. P. J.; Homan, W. J., 1997: Modification of solid woods: research and practical potential. The International Research Group on Wood Preservation, Document No.: IRG/WP 97-40098.

18. Nicholas, D. D.; Williams, A. D., 1987: Dimensional stabilization of wood with dimethylol compounds. The International Research Group on Wood Preservation. Document No.: IRG/WP 87-3412.

19. Rowell, R. M., Youngquist, J. A., Montrey, H. M., 1988: Chemical modification: adding value through new FPL composite processing technology. Forest Products Journal.

20. Rowell, R. M., 1991: Chemical modification of wood. In: Wood and Cellulosic Chemistry. Hon, D. N., Shiraishi, N. Marcel Dekker Inc., New York, pp. 703-756.

21. Shaffert; S.; Krause A.; Militz, H., 2005: Upscaling and process development for wood modification with $\mathrm{N}$ methylol compounds using superheated steam. 2nd European Conference on Wood Modification. Göttingen, Germany, pp. 161-168.

22. Torgovnikov, G. I., 1993: Interactions between the Electromagnetic Field and wood. In: Dielectric properties of wood -based materials, Springer-Verlag, Berlin. pp. 1-14. 
23. Turkulin, H.; Sell, K., 2002: Investigations into photodegradation of wood using microtensile testing. Part 4: Tensile properties and fractography of weathered wood, Holz als Roh- und Werkstoff, 63: 102-111.

24. Wepner, F., Militz, H., 2005. Fungal resistance, dimensional stability and accelerated weathering performance of N-methylol treated veneer of Fagus sylvatica. $2^{\text {nd }} \mathrm{Eu}-$ ropean conference on wood modification. Göttingen, Germany, pp 169-177.

25. Xie, Y.; Krause, A.; Militz, H.; Turkulin, H.; Richter, K.; Mai, C., 2007: Effect of treatments with 1.3-dimethylol4,5-dihydroxyethyleneurea (DMDHEU) on the tensile properties of wood. Holzforschung 61(1):43-50, http://dx.doi.org/10.1515/HF.2007.008.

\section{Corresponding address:}

Assist. Prof. BOGOSLAV ŠEFC, Ph.D.

Department of Wood Science

Faculty of Forestry, University of Zagreb

Svetošimunska 25, p.p. 422

HR-10002 Zagreb, CROATIA

e-mail: bsefc@sumfak.hr 